\title{
Online drivers and offline influences related to loyalty to airline websites
}

\author{
Santiago Forgas ${ }^{a^{*}}$, Ramon Palau $^{\mathrm{b}}$, Javier Sánchez ${ }^{\mathrm{c}}$, Rubén Huertas-García ${ }^{\mathrm{a}}$ \\ ${ }^{a}$ Department of Economics and Business, University of Barcelona, Diagonal 690, \\ 08034 Barcelona, Spain \\ ${ }^{\mathrm{b}}$ Department of Organization, Business Management and Product Design, University of \\ Girona, Alemanys 4, 17071 Girona, Spain \\ ${ }^{c}$ Department of Business Administration and Marketing, Jaume I University, Campus \\ del Riu Sec, 12071 Castelló de la Plana, Spain
}

*Corresponding author.

E-mail address: santiago.forgas@ub.edu

\section{Introduction}

The improvement of airline companies' cost efficiency has become one of the fundamental objectives in the face of a highly competitive market. The use of the Internet as a direct sales channel signifies a constant cutting-back of distribution costs in the measure that the airline companies manage to increase the percentage of users who buy their airline tickets through this channel. For the airlines it is essential to identify procedures that lead to the satisfaction, trust and loyalty of users to their website because this will permit repetition of the visit and the purchase of the ticket through this medium, as the existence of abundant information online about the competition predisposes towards disloyalty (Ruiz et al., 2009). But, although the use of the Internet is more and more general, consumers hold values, beliefs, expectations and behaviours that are maintained throughout life and create different generational identities, as demonstrated by the model of consumer socialization and cohort theory (Jackson et al., 2004). As certain values and priorities are characteristic of a generation, it seems reasonable to support the idea that differences, and a generation gap, exist in the perception of quality, satisfaction and loyalty towards airline companies' websites, between the Baby Boomers, born between 1946 and 1964, Generation X, born between 1965 and 1980, and Generation Y, born between 1981 and 1995.

For this reason this study is focussed on analyzing the antecedents of the e-loyalty of the users of airline companies' websites, differentiating them by the generation to which they belong.

\section{Conceptual background}


The most recent studies of consumer loyalty to products and services are based on the model of Oliver (1999), which posits a construct in which a consumer will pass through several phases until attaining full loyalty. In these successive phases he or she will value positively the product or service (cognitive loyalty), will continue with a favourable predisposition toward the product or service (affective loyalty) and will develop a repeated purchase intention (conative loyalty), as a step prior to the final action of purchase. Also, the research into consumer loyalty has identified that the principal antecedents of loyalty are perceived value, satisfaction and trust, for products and services in general (Singh and Sirdeshmukh, 2000), and for airline companies in particular (Forgas et al., 2010). In online transactions, we observe that researchers have defined e-loyalty as the future intention to revisit, and to purchase from, a certain website, and have identified e-satisfaction, e-trust and e-quality as the principal antecedents of e-loyalty (Flavián et al., 2006). However, very few studies relate affective e-loyalty with conative e-loyalty, so we propose the following hypothesis:

$\mathrm{H}_{1}$ : The affective loyalty of the user of an airline company's website directly and positively influences conative loyalty, this relationship being moderated by the generation to which the user belongs.

E-satisfaction is the principal antecedent of e-loyalty (Chiou, 2004) and is the result of the gap between the user's expectations and perception of the quality of the website (McKinney et al., 2002) and the general response to his/her expectations (overall satisfaction). For satisfaction to affect loyalty, frequent and accumulated satisfaction is necessary, such that the episodes of individual satisfaction are aggregated and mixed. Among the few studies of e-satisfaction and e-loyalty to airline company websites, we find that by Lubbe (2007), which investigates e-satisfaction with an airline company website, but using a construct in which to the items of overall satisfaction are added other items from constructs such as e-quality and e-loyalty. In our case, following the proposed model, and on the basis of Flavián et al. (2006), we have related overall esatisfaction to e-loyalty. For this reason we propose:

$\mathrm{H}_{2}$ : A user's satisfaction with the website of an airline company directly and positively influences the user's loyalty to the airline company's website, this relationship being moderated by the generation to which the user belongs. 
Another antecedent of e-loyalty is e-trust, which we define as a consumer's propensity to trust a website (Hsiao et al., 2010). E-trust has gained interest in the field of electronic commerce, being dealt with in several studies (Chen 2006) and the online literature has tested the antecedent relationship between e-satisfaction and e-trust (Anderson and Srinivasan, 2003). We therefore propose the following hypothesis:

$\mathrm{H}_{3}$ : A user's satisfaction with the website of an airline company directly and positively influences the user's trust in the airline company's website, this relationship being moderated by the generation to which the user belongs.

Furthermore, there is sufficient empirical evidence demonstrating that increased e-trust is related to increased intention to repeat the purchase on the website (Chang and Chen, 2008), so:

$\mathrm{H}_{4}$ : A user's trust in the website of an airline company directly and positively influences the user's loyalty to the airline company's website, this relationship being moderated by the generation to which the user belongs.

The purchase of the ticket on the company's website by the passenger is motivated by convenience factors such as 24/7 accessibility, or the speed of access to much up-to-date information (Gil et al. 2006), ease of use or the quality of information being dimensions of the quality of service in the online environment. Thus, the main antecedent of the online satisfaction, trust and loyalty dealt with in the literature is the quality of website service and the dimensions that form it. There are very few studies for evaluating the quality of tourism websites and, specifically, the websites of airline companies. Of the many dimensions proposed in the academic literature on e-quality (Ho and Lee, 2007), this study has considered four dimensions of the quality of airline companies' websites: ease of use, security/privacy, quality of information, and responsiveness.

Previous studies positively related e-quality with e-satisfaction and e-loyalty (Chang and Chen, 2008), so we propose the following hypotheses:

$\mathrm{H}_{5}$ : The quality of an airline company's website perceived by a user directly and positively influences the user's satisfaction with the company's website, this relationship being moderated by the generation to which the user belongs. 
$\mathrm{H}_{6}$ : The quality of an airline company's website perceived by a user directly and positively influences the user's loyalty to the airline company's website, this relationship being moderated by the generation to which the user belongs.

Many of the transactions that begin in the online environment are executed in the offline environment (Kim et al. 2009) and the results obtained in the latter have repercussions in the online environment. In the civil aviation sector, the airline companies have used their brands to create their websites and thus attract passengers to make their purchases through their websites, but the main service of airline companies is to carry their passengers from one destination to another. This service is performed in a real environment and therefore the relationship between customer and provider in the virtual environment is a relationship prior to another subsequent relationship that occurs in the real world and, at the same time, feeds back into the former, and so on, in those relationships that arise from the accumulation of experiences between both parties. It therefore seems logical that the value perceived offline by a user of an airline company will have a direct influence on the online environment. If we observe the academic literature on perceived value, we find that it is configured in two parts: 1) received benefits of an economic, social and relational order, and 2) sacrifices made by the consumer in terms of price, time, effort, risk and convenience (Lin et al. 2005). Companies with well-known brands benefit from the halo effect when they try to establish themselves in the online environment since consumers are more receptive to online offers of familiar brands that they trust than to offers of unknown brands (Kwon and Lennon 2009). Indeed the experiences acquired by the consumer in the real world with a brand that generates satisfaction, trust and loyalty have positively influenced the satisfaction trust and loyalty towards the websites that bear the same name (Horppu et al. 2008), so we propose the following hypotheses:

$\mathrm{H}_{7}$ : The value perceived offline by a user of an airline company directly and positively influences the user's satisfaction with the company's website, this relationship being moderated by the generation to which the user belongs.

$\mathrm{H}_{8}$ : The value perceived offline by a user of an airline company directly and positively influences the user's trust in the company's website, this relationship being moderated by the generation to which the user belongs. 
$\mathrm{H}_{9}$ : The value perceived offline by a user of an airline company directly and positively influences the user's loyalty to the company's website, this relationship being moderated by the generation to which the user belongs.

\section{[Figure 1]}

\section{Methodology}

A questionnaire was designed using 5-point Likert-type scales. For the measurement of e-quality we took into account the orientations of Benckendorff (2006). Also, to construct the ease of use and security and privacy dimensions we took as reference Casaló et al (2007). The information and responsiveness dimensions were based on Parasuraman et al (2005) and Ho and Lee (2007). For offline perceived value we worked from the study by Forgas et al. (2010) based on the GLOVAL scale by Sánchez et al (2006). Finally, to measure both satisfaction and loyalty we resorted to the studies by Oliver (1980, 1999), and to measure trust those by Doney and Cannon (1997) and Mayer et al. (1995).

A total of 1203 personal interviews were carried out in the airport of El Prat (Barcelona) with passengers of the airline company British Airways during March and April 2009. The population consisted of individuals aged over 18 years, who had travelled with the airline company at least three times during the previous year and had bought their tickets through the company website. This decision was taken due to the requisites of the model itself, which requires the accumulation of experiences with the same company. Of the total number of passengers interviewed, 378 belong to generation $\mathrm{Y}$, 403 to generation $\mathrm{X}$ and the rest (422) are baby boomers.

In the study of the data we used structural equation models by means of a multi-group analysis. The models were estimated on the matrices of variances and covariances by Robust Maximum Likelihood Estimation with EQS 6.1 statistical software (Bentler, 1995).

As for the e-quality and offline perceived value scales, the items sharing the same dimension were averaged to form composite measures (Bou-Llusar et al., 2009). Composite measures are a combination of items to create score aggregates that are then 
subjected to confirmatory factor analyses (CFA) together with the rest of the scales considered in the study in order to validate them. In CFA, the use of composite measures is useful for two reasons. Firstly, it enables us to better meet the normaldistribution assumption of maximum likelihood estimation. Secondly, it results in more parsimonious models because it reduces the number of variances and covariances to estimate, thus increasing the stability of the parameter estimations, improving the variable-to-sample-size ratio and reducing the impact of sampling error on the estimation process (Bandalos and Finney, 2001). Thus, a composite measure for each dimension was introduced as an indicator variable in the analyses conducted to assess the dimensionality, reliability and validity of the scales. Subsequently the invariance of the measuring instrument was verified, in order then to compare the regression coefficients of each of the three samples (moderator effect).

\section{Results and discussion}

With regard to the measurement of the offline value perceived by passengers of British Airways, from the confirmatory factor analysis of the 15 items that finally form the scale, we obtain four dimensions: functional value benefits (airport installations, aircraft installations, professionalism of personnel, company's service), functional value sacrifices (monetary costs and non-monetary costs), emotional value and social value. Regarding e-quality, we work with four dimensions: ease of use, security and privacy, information and responsiveness. As can be observed in table 1 the probability associated with chi-squared reaches a value greater than 0.05 (0.12478), indicating a good overall fit of the scale (Jöreskog and Sörbom, 1996). Convergent validity is demonstrated because: (1) the factor loadings are significant and higher than 0.5 (Bagozzi and Yi, 1988); and (2) the average variance extracted (AVE) for each of the factors is higher than 0.5 (Fornell and Larcker, 1981). The reliability of the scale is demonstrated because the composite reliability indices of each of the dimensions obtained is over 0.6 (Bagozzi and Yi, 1988).

\section{[Table 1]}

Table 2 shows the discriminant validity of the construct considered, evaluated through the average variance extracted -AVE (Fornell and Larcker, 1981). For this a construct must share more variance with its indicators than with other constructs of the model. 
This occurs when the square root of the AVE between each pair of factors is higher than the estimated correlation between those factors, as occurs here, thus ratifying its discriminant validity.

\section{[Table 2]}

We next analysed the psychometrical properties of the scales forming the model. As can be observed in table 3 , the probability associated with the chi-squared reaches a value greater than 0.05 (0.98798), indicating a good overall fit of the scale (Jöreskog and Sörbom, 1996). The convergent validity is demonstrated on the one hand because the factor loadings are significant and higher than 0.5 (Bagozzi and Yi, 1988), and on the other because the average variance extracted (AVE) for each of the factors is higher than 0.5 (Fornell and Larcker, 1981). As to the reliability of the scale, the composite reliability indices of each of the dimensions obtained are higher than 0.6 (Bagozzi and Yi, 1988).

\section{[Table 3]}

Table 4 shows the discriminant validity of the construct considered, as the square root of the AVE between each pair of factors is higher than the estimated correlation between those factors, ratifying its discriminant validity.

\section{[Table 4]}

\subsection{Invariance test}

As recommended by Byrne (2001), the multi-group analysis must begin with a suitably proven fit in each of the samples separately, this being considered the base model with which other more restrictive models will be compared.

As observed in table 5, the model fits well in the three separate samples, generation $\mathrm{Y}$ $\left(\chi^{2}=116.556 ; \mathrm{gl}=109\right)$, generation $\mathrm{X}\left(\chi^{2}=116.855 ; \mathrm{gl}=109\right)$ and Baby Boomers $\left(\chi^{2}=138.251 ; \mathrm{gl}=109\right)$. With regard to the simultaneous estimation of the model in both samples, to verify that the number of factors is the same, i.e. they have the same form, once again the model fits adequately $\left(\chi^{2}=389.737 ; \mathrm{gl}=327\right)$. Finally, on introducing the 
restriction of equalising the factor loadings in the three groups (metrical invariance), the model fit is observed not to be significantly worse than that of the previous step $(\Delta \chi 2=27.71 ; \Delta \mathrm{gl}=26 ; \mathrm{p}=0.3729>0,05)$, so the invariance of the factor loadings is ratified.

\section{[Table 5]}

\subsection{Causal relationships and moderator effects}

Having verified the invariance of the measuring instrument, we incorporate the structural part into the final model to establish the causal relationships. We also estimate whether there exist significant differences in the causal relationships, to analyse the moderator effect exercised by the different generational groups. We add the restrictions that will permit calculation of these significant differences among the parameters estimated, by comparing the $\chi^{2}$ of the restricted structural model with the $\chi^{2}$ of the unrestricted structural model, as shown in table (6) permitting us to test the hypotheses put forward.

Analysis of the results shows that the antecedents of conative e-loyalty are affective eloyalty, e-trust, e-satisfaction and e-quality and that these relationships are moderated by the generational group to which the sample units belong. We have also found significant differences among the three generational groups analysed (generation $\mathrm{Y}$, generation $\mathrm{X}$ and baby boomers) in the causal relationships of e-quality with esatisfaction, e-satisfaction with e-trust and affective e-loyalty with conative e-loyalty. On the other hand, in the causal relationships of offline perceived value with e-trust and e-trust with affective e-loyalty we identified significant differences only between generationally proximate groups (Y-X and $\mathrm{X}-\mathrm{BB})$.

Next, we detail the results of the causal relationships with significant differences among all the generational groups. Affective e-loyalty complies in the three generational groups with the model of Oliver (1999), acting as an antecedent of conative e-loyalty, or future intention to revisit, and purchase from, the airline company's website, verifying that this relationship is moderated by the generation to which the respondent belongs in baby boomers $(0.964)$, generation $\mathrm{X}(0.902)$, and in generation $\mathrm{Y}(0.885)$, thus confirming $\mathrm{H}_{1}$. This explains the greater significance in the baby boomers, being a generation that values professional success and are more loyal than the next generations, 
and consequently, much easier to retain as customers. Regarding the causal relationship between e-satisfaction and e-trust, we have verified that e-satisfaction exercises a positive influence on e-trust, the generational moderator effect also being demonstrated by higher values for the baby boomers $(0.760)$ than for generations $Y(0.707)$ and $X$ (0.607), confirming $\mathrm{H}_{3}$. A explanation for this could be that valuing satisfaction requires a certain degree of attention to detail, meticulousness and spirit of sacrifice, characteristics associated with Baby Boomers. Regarding the relationship of website equality with user e-satisfaction, the influence exercised by website e-quality over esatisfaction is also fulfilled, the generation emerging as a moderator. The influence of the generation Y group (0.963), a generation that was born playing with computers and gathers information through information technologies, is more significant than those of the baby boomers $(0.942)$ and generation $\mathrm{X}(0.857)$, confirming $\mathrm{H}_{5}$.

We next set out the results of the causal relationships with significant differences between the groups with greatest generational proximity, explaining these differences because the later generation is always radically different from the earlier one. We thus verify that e-trust exercises a direct and positive influence over affective e-loyalty, producing the generational moderator effect between generations $\mathrm{Y}$ and $\mathrm{X}$ and between generation $\mathrm{X}$ and the Baby Boomers, so partially confirming $\mathrm{H}_{4}$. As to the influence of offline perceived value on e-trust, we find that this relationship is fulfilled, but the generational moderator effect also occurs only between generations $\mathrm{Y}$ and $\mathrm{X}$ and between generation $\mathrm{X}$ and the Baby Boomers, so partially confirming $\mathrm{H}_{8}$. We have not found any direct relationships demonstrating the influence of esatisfaction, e-quality and offline perceived value over e-loyalty, so $\mathrm{H}_{2}, \mathrm{H}_{6}$ and $\mathrm{H}_{9}$ are rejected, nor the relationship between offline perceived value and e-satisfaction, so $\mathrm{H}_{7}$ is rejected.

\section{[Table 6]}

\section{Conclusions}

The results of the study show that achieving the conative e-loyalty of a user of an airline company website is not a direct process but must follow the stages demonstrated in the study. Thus, the antecedent of conative e-loyalty is affective e-loyalty, the latter being achieved through e-trust, and at the same time, to generate e-trust, e-satisfaction and a positive offline perceived value of the airline company must be achieved. Also, the 
antecedent of e-satisfaction is e-quality. This means that in order to maintain and increase the number of users of airline companies' websites, it is of great importance to work on users' trust through continued improvement of the quality of the website, particularly in the quality of information and in ease of use, in the functional benefits seen as critical in the performance of airline companies' traditional services (punctuality, good timetables, attention to complaints), aircraft installations and professionalism of personnel, as well as in developing feelings, emotions and sensations that will positively influence the passenger.

Significant differences are detected between the generational groups analysed, which means that the airline companies must take into account the characteristics of these three generational segments in the design of their websites. The key point emerging from the study is that Baby Boomers are more loyal, and consequently have more intention to recommend, revisit and purchase through the website, than generations $\mathrm{X}$ and $\mathrm{Y}$, which, should drive the airline companies to develop more loyalty programs for these two groups with the objective of increasing their levels of loyalty and avoiding the purchase of tickets through other online intermediaries with more aggressive loyalty policies.

\section{References}

Anderson, R.E.; Srinivasan, S.S., 2003. E-satisfaction and e-loyalty: a contingency framework. Psychology and Marketing 20, 123-138.

Bagozzi, R.P., Yi, T., 1988. On the evaluation of structural equation models. Journal of the Academy of Marketing Science, 16(1), 74 - 94.

Bandalos, D.L., Finney, S.J., 2001. Item parceling issues in structural equation modeling. In Marcoulides, G.A., \& Schumacker, R.E. (Eds.). Advanced structural equation modeling: New developments and techniques. Lawrence Erlbaum Associates, Mahwah, NJ.

Benckendorff, P. (2006). “An exploratory analysis of traveler preferences for airline website content”. Journal of Information Technology and Tourism. Vol. 8, pp. 149 159

Bentler, P.M., 1995. EQS Structural equations program manual. Multivariate Software Inc., Encino, CA. 
Bou, J.C., Escrig, A.B., Roca, V., \& Beltrán, I., 2009. An empirical assessment of the EFQM excellence model: Evaluation as a TQM framework relative to the MBNQA model. Journal of Operations Management 27(1), 1-22.

Byrne, B.M., 2001. Structural equation modelling with AMOS: Basic concepts, applications and programming. Lawrence Erlbaum Associates, Inc., Mahwah, NJ

Casaló, L.V., Flavián, C., Guinalíu, M. 2007. The role of security, privacy, usability and reputation in the development of online banking. Online Information Review 31(5), 583-603.

Chang, H.H., Chen, S.W., 2008. The impact of online store environment cues on purchase intention. Online Information Review 32(6), 818-841.

Chen, C., 2006. Identifying Significant Factors Influencing Consumer Trust in an Online Travel Site. Information Technology and Tourism 8, 3, 197-214.

Chiou, J.S., 2004. The antecedents of consumers' loyalty toward Internet Service Provider. Information \& Management 41, 685-695.

Doney, P., and Cannon, J. An examination of the nature of trust in the buyer-seller relationship. Journal of Marketing, 61, 2, 1997, 35-51.

Flavián, C., Guinalíu, M., Gurrea, R., 2006. The role played by perceived usability, satisfaction and consumer trust in website loyalty. Information \& Management 43, $1-14$.

Forgas, S., Moliner, M.A., Sánchez, J., Palau, R., 2010, Antecedents of airline passenger loyalty: Low-cost versus traditional airlines. Journal of Air Transport Management 16(4), 229-233.

Fornell, C., Larcker, D.F., 1981. Evaluating structural equations models with unobservable variables and measurement error. Journal of Marketing Research 18(1), 39-50

Gil, M., Young, D., Won, T., 2006. Impact of e-business on air travel markets: Distribution of airline tickets in Korea. Journal of Air Transport Management 12, 253-260.

Ho, Ch.I., Lee,Y-L, 2007. The development of an e-travel service quality scale. Tourism Management, 28(6) 1434-1449.

Horppu, M., Kuivalainen, O., Tarkiainen, A., Ellonen, H-K., 2008. Online satisfaction, trust and loyalty, and the impact of the offline parent brand. Journal of Product and Brand Management 17(6), 403-413. 
Hsiao, K.L., Lin, J.C.C., Wang, X.Y., Lu, H.P., Yu, H., 2010, Antecedents and consequences of trust in online product recommendations. An Empirical study in social shopping. Online Information Review 34(6), 935-953.

Jackson, V., Stoel, L., Brantley, A., 2011. Mall attributes and shopping value: Differences by gender and generational cohort. Journal of Retailing and Consumer Services 18, 1-9.

Jöreskog, K.G., Sörbom, D., 1996. LISREL 8: User's Reference Guide. Scientific Software, Chicago.

Kim, J., Jin, B., and Swinney, J.L., 2009. The role of retail quality, e-satisfaction and etrust in online loyalty development process. Journal of Retailing and Consumer Services 16(4), 239-247.

Kwon, W. S., Lennon, S. J., 2009. What induces online loyalty? Online versus offline brand images. Journal of Business Research 62(5), 557-564.

Lin, Ch-H., Sher, P.J., Shih, H-Y, 2005. Past progress and future directions in conceptualizing customer perceived value. International Journal of Service Industry Management 16(4), 318-336.

Lubbe, B., 2007. The effect of Internet apprehension and website satisfaction on air travellers' adoption of an airline's website. Journal of Air Transport Management $13,75-80$.

Mayer, R., Davis, J., Shoorman, F. 1995. An integrative model of organizational trust. Academy of Management Review 20(3), 709-734.

McKinney, V., Yoon, K., Zahedi, F., 2002. The measurement of web-customer satisfaction: an expectation and disconfirmation approach. Information Systems Research 13(3), 296-315.

Oliver, R. L., 1980. A Cognitive Model of the Antecedents and Consequences of Satisfaction Decisions. Journal of Marketing Research 17(4), 460-469.

Oliver, R. L., 1999. Whence consumer Loyalty?. Journal of Marketing, 63, 33-45.

Parasuraman, A., Zeithaml, V.A., and Malhotra, A., 2005. E-S-QUAL: A Multiple-Item Scale for Assessing Electronic Service Quality. Journal of Service Research 7(3), 213-233.

Ruiz, C., Sanz, S., Aldás, J., (2009). Drivers and barriers to online ticket purchasing. Journal of Air Transport Management 15, 294-298.

Sánchez, J., Callarisa, L., Rodríguez, R.M., \& Moliner, M.A., 2006. Perceived value of the purchase of a tourism product. Tourism Management 27(6), 394-409. 
Singh, J., Sirdeshmukh, D., 2000. Agency and trust mechanisms in consumer satisfaction and loyalty judgements. Journal of Academy of Marketing Science 28, $150-167$

Table 1. Sample profile

\begin{tabular}{lcc}
\hline Demographic characteristics & Number & Frequency (\%) \\
\hline Gender & & \\
$\quad$ Male & 650 & 54.03 \\
Female & 553 & 45.97 \\
Generational cohort & 378 & 31.42 \\
18-28 (generation Y, born from1981 to 1995) & 403 & 33.50 \\
29-44 (generation X, born from 1965 to 1980) & 422 & 35.08 \\
45-63 (baby boomers, born from 1946 to 1964) & & \\
Occupation & 493 & 40.98 \\
Employee & 213 & 17.71 \\
Self-employed & 210 & 17.46 \\
Students & 22 & 1.83 \\
Retired & 265 & 22.02 \\
$\quad$ Others & & \\
Education & 760 & 63.18 \\
$\quad$ University degree & 443 & 36.82 \\
$\quad$ Non University & & 34.08 \\
Income of households & 410 & 17.96 \\
$\quad$ Below average & 577 & \\
Average & 216 & \\
Above average & & \\
\hline
\end{tabular}

Table 2. Analysis of the dimensionality, reliability and validity of the e-quality scale (Fully standardized solution)

\begin{tabular}{ll}
\hline Items & Factor \\
& loading \\
\hline Ease of use (CR=0.89; AVE=0.76) & $0.86^{\ddagger}$ \\
The company's website is easy to use & $0.87^{* *}$ \\
It is easy to find the information I am looking for (schedules, flights) & $0.83^{* *}$ \\
It is easy to make the booking & $0.82^{\ddagger}$ \\
Security and privacy (CR=0.86; AVE=0.66) & $0.80^{* *}$ \\
I feel secure with the electronic payment system of this company & $0.79^{* *}$ \\
The website has the technical capacity to ensure that my data will not & $0.69^{* *}$ \\
be intercepted by third parties & \\
I feel safe giving the company my personal data & $0.79^{\ddagger}$ \\
The website does not use my personal data without my consent & $0.81^{* *}$ \\
Information (CR=0.82; AVE=0.66) & $0.72^{* *}$ \\
The information of the website is good, accurate and concise & \\
The information is useful and resolves doubts & $0.89^{*}$ \\
The website provides me with information adapted to my preferences & $0.87^{* *}$ \\
Responsiveness (CR=0.87; AVE=0.79) & \\
I think that in the event of problems (complaints) they respond quickly &
\end{tabular}


Note: Fit of the model: Chi-squared=56.0640, $\mathrm{df}=45, \mathrm{P}=0.12478 ; \mathrm{RMSEA}=0.042 ; \mathrm{GFI}=0.98$;

AGFI $=0.966$

$\mathrm{CR}=$ Composite reliability

AVE $=$ Average Variance Extracted

${ }^{\ddagger}$ Fix parameter

* Significant parameter at 0.05 ( $\mathrm{t}$ value $>1.96)$

** Significant parameter at 0.01 (t value $>2.56)$

Table 3

Discriminant validity of the scales associated with e-quality

$\begin{array}{llll}1 & 2 & 3 & 4\end{array}$

$\begin{array}{lllll}\text { 1. Ease of use } & 0.90 & & & \\ \text { 2. Security and privacy } & 0.29 & 0.81 & & \\ \text { 3. Information } & 0.33 & 0.29 & 0.81 & \\ \text { 4. Responsiveness } & 0.21 & 0.33 & 0.33 & 0.89\end{array}$

Below the diagonal: estimated correlation between the factors.

Diagonal: square root of AVE.

Table 4. Analysis of the dimensionality, reliability and validity of the scales of measurement (Fully standardized solution)

\begin{tabular}{ll} 
Items & Factor \\
& loading \\
\hline E-quality (CR=0.79; AVE=0.57) & $0.75^{\ddagger}$ \\
Ease of use & $0.66^{* *}$ \\
Security and privacy & $0.79^{* *}$ \\
Information & $0.57^{* *}$ \\
Responsiveness & \\
Perceived value (CR=0.88; AVE=0.70) & \\
Functional value: Benefits (airport and aircraft installations, & $0.88^{*}$ \\
Professionalism of personnel, airline services) & $0.62^{* *}$ \\
Functional value: Sacrifices (fares and time waiting) & $0.87^{* *}$ \\
Emotional value (happy, calm, good vibes with the airline) & \\
Social value (good image, better image than its competitors, & $0.80^{* *}$ \\
accepted by family and relatives) & \\
E-Satisfaction (CR=0.87; AVE=0.73) & $0.84^{*}$ \\
The website meets my expectations & $0.79^{* *}$ \\
All the contacts with the company website are satisfactory & $0.86^{* *}$ \\
In general I am satisfied with the company's website & \\
E-Trust (CR=0.86; AVE=0.67) & $0.79^{\ddagger}$ \\
The information offered by the website is sincere and honest & $0.82^{* *}$ \\
In general the website fulfils its commitments & $0.72^{* *}$ \\
The website takes an interest in its users' needs & $0.78^{* *}$ \\
The website has the technical capacity to do its job well & $0.90^{\ddagger}$ \\
Affective e-loyalty (CR=0.91; AVE=0.84) & $0.91^{* *}$ \\
I like the company's website & $0.84^{*}$ \\
I think it is a good website & $0.88^{* *}$ \\
Conative e-loyalty (CR=0.77; AVE=0.87) & \\
I shall continue to buy from the company's website & \\
I shall continue to recommend the company's website & \\
\hline
\end{tabular}


Note: Fit of the model: Chi-squared=44.4461, df=68, P=0.98798; RMSEA=0.001; GFI=0.995;

AGFI $=0.986$.

$\mathrm{CR}=$ Composite reliability

AVE $=$ Average Variance Extracted

${ }^{\ddagger}$ Fix parameter

* Significant parameter at 0.05 (t value $>1.96)$

** Significant parameter at 0.01 (t value $>2.56)$.

Table 5

Discriminant validity of the scales associated with the model

$\begin{array}{llllll}1 & 2 & 3 & 4 & 5 & 6\end{array}$

1. E-quality

0.75

2. Perceived value

$0.24 \quad 0.83$

3. E-satisfaction

$\begin{array}{lll}0.25 & 0.32 & 0.85\end{array}$

4. E-trust

$\begin{array}{llll}0.26 & 0.31 & 0.35 & 0.81\end{array}$

5. Affective e-loyalty

$\begin{array}{llll}0.29 & 0.33 & 0.39 & 0.37\end{array}$

6. Conative e-loyalty

$\begin{array}{llllll}0.28 & 0.32 & 0.36 & 0.33 & 0.44 & 0.87\end{array}$

Below the diagonal: estimated correlation between the factors.

Diagonal: square root of AVE.

Table 6. Relationships obtained

\begin{tabular}{|c|c|c|c|c|c|c|c|c|c|}
\hline \multicolumn{2}{|c|}{ Hypothesis } & Path & $\begin{array}{c}\text { GY } \\
\text { Parameter }\end{array}$ & $\begin{array}{c}\text { GX } \\
\text { Parameter }\end{array}$ & \multirow{2}{*}{$\begin{array}{c}\begin{array}{c}\mathrm{BB} \\
\mathrm{r} \\
\text { Parameter }\end{array} \\
0.964 * *\end{array}$} & \multirow{2}{*}{$\begin{array}{r}\text { GY-GX } \\
\Delta \chi 2 \\
25.32^{\star}\end{array}$} & \multirow{2}{*}{$\begin{array}{c}\text { GY-BB } \\
\Delta \chi 2 \\
4.16^{\star}\end{array}$} & $\begin{array}{c}\mathrm{GX}-\mathrm{BB} \\
\Delta \chi^{2}\end{array}$ & Results \\
\hline $\mathrm{H}_{1}$ & $\Delta f f e c t i$ & & 1. $0.885^{* *}$ & $0.902 * *$ & & & & $24.13^{\star}$ & \\
\hline $\mathrm{H}_{3}$ & E-Sat & $n \rightarrow$ trust & $0.707 * *$ & $0.607 * *$ & $0.760 * *$ & & & & Supportec \\
\hline $\mathrm{H}_{4}$ & E-trus & fective & $0.957 * *$ & $0.969 * *$ & $0.925 * *$ & $22.86^{\star}$ & $3.05^{\star}$ & $22.83^{\star}$ & Partially \\
\hline $\mathrm{H}_{5}$ & E-Qua & $\rightarrow$ e-satisfaction & $0.963 * *$ & $0.857 * *$ & $0.942 * *$ & $7.33^{\star}$ & $25.30^{\star}$ & $22.11^{\star}$ & Supportec \\
\hline $\mathrm{H}_{8}$ & Offline & erceived value $\rightarrow$ e-trust & $0.276^{* *}$ & $0.388 * *$ & $0.258 * *$ & $9.36^{\star}$ & $1.33^{\star}$ & $24.84^{\star}$ & Partially \\
\hline
\end{tabular}

Note: $\mathrm{GY}=$ Generation $\mathrm{Y} ; \mathrm{GX}=$ Generation $\mathrm{X} ; \mathrm{BB}=$ Baby Boomers

* Significant parameter at 0.05 (t value $>1.96$ )

** Significant parameter at 0.01 (t value $>2.56$ ).

$\mathrm{P}>0.05$

$\rightarrow \mathrm{P}<0.05$ 
Fig.1. The proposed structural model

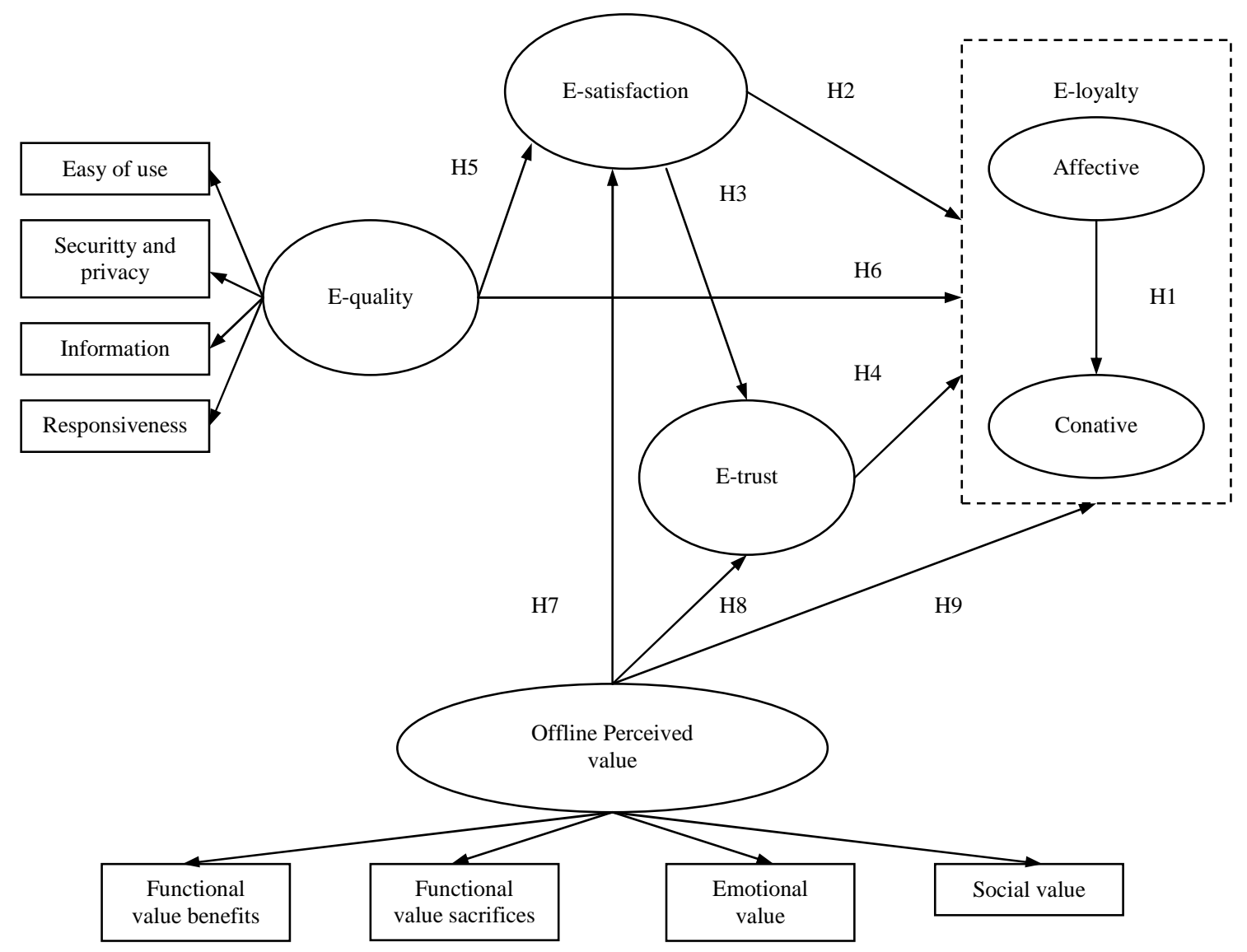

